ISSN: $2617-6548$

\title{
Valorization of Lower Grade Resin, Bark, and Fruit of Styrax Sumatrana
}

Muhammad Yusuf Abduh ${ }^{1 *}$, Ananda Teli Rahmanita ${ }^{2}$, Elga Ridho Maulana ${ }^{3}$, Valenikhe Fitri Nadhira ${ }^{4}$, Tjokorda Istri Indira $^{5}$, Dobert Manurung ${ }^{6}$

${ }^{1}$ School of Life Sciences and Technology, Bandung Institute of Technology, and University Center of Excellent for Nutraceutical,
Bioscience and Biotechnology Research Center, Institute Technology Bandung, Indonesia.
2,4,5,6 School of Life Sciences and Technology, Bandung Institute of Technology, Indonesia.
${ }^{3}$ University Center of Excellent for Nutraceutical, Bioscience and Biotechnology Research Center, Institute Technology Bandung,
Indonesia.

*Corresponding author: Muhammad Yusuf Abduh (Email: yusuf@sith.itb.ac.id)

\begin{abstract}
Styrax sumatrana or the kemenyan tree grows in North Sumatera, Indonesia, and its resin is commonly utilized by the local community. Other parts of kemenyan, such as barks and fruits contain valuable compounds that can be extracted to produce high-value bioproducts. This study examined the effect of different resin grades on the physical parameters and cinnamic acid content, delignification pre-treatment period of kemenyan barks with Phanerocahete chrysosporium on the amount of extracted saponin from the barks, and different fruit ripeness on the composition of the fruits. This study showed that grade IV, V and VI resin contain 21.78 to $24.89 \%$ cinnamic acid. The isolated cinnamic acid had a purity of 90.9 to $94.3 \%$. Pretreatments of kemenyan barks were able to degrade $15 \%$ of the lignin after 21 days of incubation with Phanerochaete chrysosporium. and increased the amount of extracted saponin up to 7.5 -fold higher compared to the non-pre-treated barks. Ripe kemenyan fruits had a higher protein $(4.27-10.23 \%)$ and crude fat $(0.91-7.36 \%)$ content as compared to the unripe fruits. Fatty acid composition of the crude fat had been determined and primarily consists of linoleic acid (31.71-42.33\%) and palmitic acid (30.44-30.82\%) for both ripe and unripe fruits.
\end{abstract}

Keywords: Cinnamic acid, Delignification, Phanerochaete chrysosporium, Resin, Saponin, Styrax sumatrana.

DOI: 10.53894 /ijirss.v5i1.349

Funding: Authors would like to thanks Institute Technology Bandung for funding this study (Grant number: PPMI-KK-ATB-2021).

History: Received: 22 November 2021/Revised: 7 January 2022/Accepted: 24 January 2022/Published: 9 February 2022

Copyright: () 2022 by the authors. This article is an open access article distributed under the terms and conditions of the Creative Commons Attribution (CC BY) license_https://creativecommons.org/licenses/by/4.0/).

Authors' Contributions: All authors contributed equally to the conception and design of the study.

Competing Interests: The authors declare that they have no competing interests.

Transparency: The authors confirm that the manuscript is an honest, accurate, and transparent account of the study; that no vital features of the study have been omitted; and that any discrepancies from the study as planned have been explained.

Ethical: This study followed all ethical practices during writing.

Publisher: Innovative Research Publishing

\section{Introduction}

Styrax sumatrana belongs to the genus Styrax in Styracaceae and is known for the synthesis of resinous material [1]. Styrax sumatrana, also known as kemenyan, is endemic in Indonesia and widely distributed in North Sumatera. In 2017, 
Styrax sumatrana covered up to 23,068 ha with a total production of 8,332 tones [2]. The main product of kemenyan is benzoid resin, a non-timber forest product locally known as kemenyan resin with a high economical value [3], and is widely used in various ritual ceremonies, as well as being used for cosmetic and medicinal purposes [4,5]. The market price of the resin varies for different grades which depends on several important factors, particularly size, odor, color, and fragility. Iswanto, et al. [6]. Aswandi and Kholibrina [7] have determined that the physico-chemical properties of the kemenyan resin vary for different grades. The local Grade I of kemenyan resin obtained from a community forest in North Sumatera, Indonesia has the highest purity and balsamic acid content as well as lower ash content, melting point, and moisture content [7]. It also has been reported that the kemenyan resin from North Sumatera mainly comprises of cinnamic acid and ethyl cinnamate, which indicates a high quality of the resin as compared to the resin obtained from other places [5]. The kemenyan resin is commonly harvested from the trees by a tapping process. After the tapping process, the resin is separated from the bark. Very often, the bark is used as incense that has a relatively low price, USD $2 / \mathrm{kg}-5 / \mathrm{kg}$ [8]. The economic value of the kemenyan bark can be increased by further extracting saponin that has a higher price of approximately USD 5/g from the bark [9]. However, the extraction process of saponin from the kemenyan bark is hindered by the high lignin content of the bark. An alternative way to overcome this limitation is through pre-treatment of the bark with white-rot fungi to reduce the lignin content of the bark [10]. However, previous studies on the delignification of kemenyan bark for the extraction of saponin are very scarce. In addition, very limited information in the open literature is available on the valorization of kemenyan fruit despite its adequate productivity. Scientific studies on the composition of kemenyan fruit would provide an insight on its potential valorization to increase the economic value of kemenyan plantations. Hence, this study was carried out to determine the potential valorization of the kemenyan resin, bark, and fruit by examining the cinnamic acid content of the kemenyan resin based on an existing local grading system, pre-treatment of kemenyan bark with white-rot fungi to increase the yield of extracted saponin, and identifying the composition of the kemenyan fruit at different maturity levels.

\section{Materials and Methods}

\subsection{Materials}

Kemenyan resin (grade IV, V and VI), bark and fruit (ripe and unripe) were obtained from a local kemenyan plantation at Humbang Hasundutan, North Sumatera, Indonesia. The samples were taken from kemenyan trees between 7-8 years old. White-rot fungi (Phanerocahete chrysosporium) was obtained from Microbiology Laboratory, School of Life Sciences and Technology, Institut Teknologi Bandung, Indonesia. Ethanol, $\mathrm{KOH}$, distilled water, $\mathrm{HCl}, \mathrm{NaHCO}_{3}, \mathrm{NaOH}$, ethyl acetate, and n-hexane were also obtained from School of Life Sciences and Technology, Institut Teknologi Bandung, Indonesia.

\subsection{Determination of Moisture Content}

Moisture content of the kemenyan resin was determined by using a Moisture Analyzer HB43-S (Mettler Toledo, USA). The moisture content of the kemenyan fruit was measured by using a drying method. Each part of the fruit, particularly exocarp, mesocarp, endocarp and endosperm were dried for $24 \mathrm{~h}$ in an oven at $103^{\circ} \mathrm{C}$ until constant weight [11]. The fruit parts were then crushed using a blender and filtered using a 60-mesh sieve for further analysis.

\subsection{Determination of Resin Impurity}

Impurity content in the kemenyan resin was determined by dissolving the resin $(2 \mathrm{~g})$ in ethanol $(25 \mathrm{~mL})$ using an Erlenmeyer flask as suggested by Waluyo, et al. [12]. The solution was filtered using a filter paper. The residue was then washed by ethanol and dried in an oven at $103^{\circ} \mathrm{C}$ until constant weight. The impurity content in the resin was calculated using Equation 1.

$$
\text { Moisture content }=\frac{\left(w W_{\text {fruit }}-D W_{\text {fruit }}\right)}{W W_{\text {fruit }}} \times 100 \%
$$

Where $\mathrm{DW}_{\text {residue, }}$ is the weight of dried residue $(\mathrm{g}), \mathrm{DW}_{\text {residue, }}$ is the weight of residue before washing and drying $(\mathrm{g})$ and $\mathrm{W}_{\text {resin }}$ is the initial weight of the resin $(\mathrm{g})$.

\subsection{Determination of Cinnamic Acid Content}

Cinnamic acid content in the kemenyan resin was determined through a gradual extraction method as suggested by Waluyo, et al. [12]. Kemenyan resin $(1.5 \mathrm{~g})$ was mixed with $25 \mathrm{~mL}$ of $0.5 \mathrm{~N}$ potassium hydroxide-ethanol solutions and incubated for $1 \mathrm{~h}$ in an Erlenmeyer flask. After that, the ethanol inside the mixture was evaporated. The mixture was added with $50 \mathrm{~mL}$ of hot distilled and homogenized water. After the mixture was cooled, another $80 \mathrm{~mL}$ of distilled water was added to the mixture along with $50 \mathrm{~mL}$ of $3 \%$ magnesium sulfate solution. The mixture was then homogenized and incubated for $10 \mathrm{~min}$, then filtered using a filter paper, and the obtained residue was washed with $20 \mathrm{~mL}$ of distilled water. The filtrate and water from the washing process were acidized with $15 \mathrm{~mL}$ of $4 \mathrm{~N} \mathrm{HCl}$ and then extracted 4 times with $20 \mathrm{~mL}$ of dichloromethane. The dichloromethane phase was collected and then extracted again with $70 \mathrm{~mL}$ of $5 \% \mathrm{NaHCO}_{3}$ solution. The formed water phase was collected and then washed with dichloromethane.

Afterwards, the water phase was acidized with $15 \mathrm{~mL}$ of $4 \mathrm{~N} \mathrm{HCl}$ and then extracted with $70 \mathrm{~mL}$ of chloroform. The chloroform phase was collected and then vaporized until the residue was obtained. It was then mixed with hot water, filtered, and cooled. The attained crystal was filtered, washed with cool water, and dried in an oven at $105^{\circ} \mathrm{C}$ for $2 \mathrm{~h}$. The dried crystal was specified as cinnamic acid crystal. The cinnamic acid content in the kemenyan resin was calculated using Equation 2.

$$
\text { Cinnamic acid content }=\frac{D W_{\text {crystal }}}{W_{\text {resin }}} \times 100 \%
$$

Where $\mathrm{DW}_{\text {crystal }}$ is the weight of dried cinnamic acid crystal (g) and $\mathrm{W}_{\text {resin }}$ is the initial weight of resin. 
Additionally, $0.1 \mathrm{~g}$ of cinnamic acid crystal was dissolved in $20 \mathrm{~mL}$ of ethanol in an Erlenmeyer flask. The mixture was heated in an oven at $50^{\circ} \mathrm{C}$ for $1 \mathrm{~h}$ and then tittered with $0.5 \mathrm{~N} \mathrm{NaOH}$, with phenolphthalein as an indicator, until the color of the mixture changed from yellow to reddish orange [12]. This procedure was conducted to measure the purity of cinnamic acid, and the purity can be calculated using Equation 3.

$$
\text { Cinnamic acid purity }=\frac{\left(V_{\mathrm{NaOH}} \times \mathrm{N}_{\mathrm{NaOH}} \times 148.2\right)}{D W_{\text {crystal }}}
$$

Where $\mathrm{V}_{\mathrm{NaOH}}$ is the volume of applied $\mathrm{NaOH}(\mathrm{mL}), \mathrm{N}_{\mathrm{NaOH}}$ is the normality of applied $\mathrm{NaOH}(\mathrm{N}), 148.2$ is the equivalent weight of cinnamic acid (g/eq), and DW crystal is the weight of cinnamic acid crystal (mg).

\subsection{Thin Layer Chromatography Analysis}

Cinnamic acid crystal was dissolved in chloroform. A small amount of the solution was placed on a thin layer chromatography (TLC) plate by using a capillary pipette as suggested by Waluyo, et al. [12]. Silica was used as a stationary phase of the TLC plate. Mixtures of ethyl acetate and n-hexane, with ratios of 1:9, 1:1, 7:3, 8:2 and 1:0, were used as the eluent and added to a container. The plate was then observed under the ultraviolet (UV) lamp to detect the spot that was formed due to the elution. The retention factor value can be calculated according to Equation 4.

$$
R f=\frac{x_{\text {spot }}}{x_{\text {eluent }}}
$$

Where $\mathrm{R}_{\mathrm{f}}$ is the retention factor value of cinnamic acid, $\mathrm{x}_{\text {spot }}$ is the distance between the cinnamic acid spot and the lower boundary on the TLC plate $(\mathrm{cm})$, and $\mathrm{x}_{\text {eluent }}$ is the distance between the upper and lower boundary of TLC plate (cm).

Similar steps were applied for the TLC analysis of saponin, however, the sample was first dissolved in ethanol. The applied eluent was the mixture of chloroform: methanol: water with a ratio of 70:44:10. After the elution process, the TLC plate was sprayed with Liebermann-Burchard reagent.

\subsection{Pre-Treatment of Kemenyan Barks}

Kemenyan barks were crushed using a blender, with samples ( $4 \mathrm{~g})$ then being mixed with PDA $(5 \mathrm{~mL})$ and $0.17 \%$ of inorganic salt solution inside a petri dish. The $\mathrm{pH}$ of the medium was set at 4.5 . The petri dish was then autoclaved at $121^{\circ} \mathrm{C}$ for $15 \mathrm{~min}$ (Lerouge, 2019). Afterwards, $P$. chrysosporium (approximate size of $\pm 6 \mathrm{~mm}$ ) was added to the petri dish and incubated for $0 \mathrm{~d}, 7 \mathrm{~d}, 14 \mathrm{~d}$ and $21 \mathrm{~d}$.

\subsection{Qualitative and Quantitative Analysis of Saponin}

Qualitative analysis was carried out to determine the presence of saponin from the kemenyan bark samples. The kemenyan barks were crushed with a blender. The crushed sample $(2 \mathrm{~g})$ was boiled with distilled water $(10 \mathrm{~mL})$. The mixture was then filtered, gently shaken, followed by an additional 3 drops of $\mathrm{HCl}$, and shaken again. Afterwards, the resulting foam was observed [13]. For quantitative analysis of saponin, $50 \mathrm{~mL}$ of $20 \%$ ethanol was added to the crushed kemenyan bark samples $(10 \mathrm{~g})$ and then heated. The mixture was mixed continuously using a magnetic stirrer at $55^{\circ} \mathrm{C}$ for $4 \mathrm{~h}$. The mixture was filtered, and the resulting residue was added with $100 \mathrm{~mL}$ of $20 \%$ ethanol. The extract from the first and second extraction were collected and vaporized until the volume of the solution was $40 \mathrm{~mL}$. The concentrate was then extracted with $50 \mathrm{~mL}$ of chloroform 3 times. After that, the chloroform was separated, and the extract solution was added with $30 \mathrm{~mL}$ of propanol. The solution was then dried, and the residue was weighed to determine the amount of extracted saponin.

\subsection{Isolation of Lipid from Kemenyan Fruits}

Isolation of lipid from the kemenyan fruits was carried out using a Soxhlet method as suggested by Prada, et al. [14]. Dried kemenyan fruits $(3 \mathrm{~g})$ were extracted with $300 \mathrm{~mL}$ of $\mathrm{n}$-hexane for $6 \mathrm{~h}$ at a temperature of $60-70^{\circ} \mathrm{C}$. The lipid extract was separated from the solvent by using a rotary evaporator at $40 \mathrm{rpm}, 60^{\circ} \mathrm{C}$ and $360 \mathrm{mbar}$.

\subsection{Analytical Methods}

Fatty acid composition of lipid isolated from the kemenyan fruit was carried out at the Analytical Chemistry Academy (Bogor, Indonesia) by using a Gas Chromatography - Mass Spectrometry (GC-MS) with 19091S-433 GC Column (Agilent, USA). The temperature was set at $40^{\circ} \mathrm{C}$ for $2 \mathrm{~min}$ and then increased to 5 min and reached $280^{\circ} \mathrm{C}$. Helium gas was applied as the eluent with a pressure of $7.07 \mathrm{psi}$, a flowrate of $50 \mathrm{~mL} / \mathrm{min}$ and a split ratio of 100:1. A proximate analysis of the kemenyan fruit was carried out at the Analytical Laboratory, University of Padjajaran, Jatinangor. The lignocellulose content of kemenyan bark and fruit was determined using a Chesson-Datta method [15].

\section{Results and Discussion}

\subsection{Characteristics of Kemenyan Resin}

Important characteristics of kemenyan resin (grade IV, V and VI) from Humbang Hasundutan, North Sumatera, Indonesia have been determined and the results are shown in Table 1. The size of grade IV resin lies in the range of 1-2 $\mathrm{cm}$ whereas the size of grade $\mathrm{V}$ resin was less than $1 \mathrm{~cm}$ and fine particles were observed for grade VI resin. The color of the resin varies from light to reddish yellow for grade IV resin and light reddish brown for grade V and VI resin. The size and color of the resin observed in this study resembles the current grading system practiced by the farmers in Indonesia as reported by Aswandi and Kholibrina [7]. The price of grade IV to grade VI resin is lower than the price of grade I to III due to smaller resin size and also due to the change in color of resin from pure white to become more brownish. Grade IV to grade VI resins have a smaller resin size because the grade IV resin was typically obtained after third harvest from kemenyan bark whereas 
grade V resin was collected during bark cleansing and the remaining resin was categorized as grade VI [7].

Table 1.

Characteristic of kemenyan resin obtained from North Sumatera, Indonesia.

\begin{tabular}{l|c|c|c|c|c|c}
\hline \multirow{2}{*}{ Grade } & \multirow{2}{*}{ Size } & Color & \multirow{2}{*}{$\begin{array}{c}\text { Moisture } \\
\text { content (\%) }\end{array}$} & $\begin{array}{c}\text { Impurity } \\
(\boldsymbol{\%})\end{array}$ & \multicolumn{2}{|c}{ Cinnamic acid } \\
\cline { 3 - 7 } & & & Content (\%) & Purity (\%) \\
\hline IV & $1-2 \mathrm{~cm}$ & Light to reddish yellow & $0.74 \pm 0.10$ & $1.69 \pm 0.44$ & $24.89 \pm 1.38$ & $91.8 \pm 2.09$ \\
\hline V & $<1 \mathrm{~cm}$ & Light reddish brown & $0.97 \pm 0.11$ & $3.84 \pm 0.09$ & $22.00 \pm 0.67$ & $94.3 \pm 0.85$ \\
\hline VI & Fine particles & Light reddish brown & $1.41 \pm 0.10$ & $5.38 \pm 0.39$ & $21.78 \pm 1.67$ & $90.9 \pm 0.85$ \\
\hline
\end{tabular}

As well as size and color, moisture content also affects the quality of a resin. Resin can become stickier due to a high moisture content caused by the water-insoluble components contained within, such as cinnamic acid that has a low water solubility [16]. As can be seen from Table 1 , the moisture content of the resin varies from $0.74 \%$ for Grade IV to $1.41 \%$ for Grade VI. This result indicates that a higher quality resin has a relatively lower moisture content which resembles the previous findings by Aswandi and Kholibrina [7] that the moisture content of kemenyan resin increased from 2.26\% for Grade I resin to $3.10 \%$ for Grade VI resin. The low moisture content of kemenyan resin in this study suggested that the resin samples have been previously dried by the farmers, typically by shade drying for several days until the resin is dried [8].

Table 1 shows that the percentage of impurity increased from $1.69 \%$ for grade IV to $5.38 \%$ for grade VI resin. The impurities may comprise of barks, ash and other components that stick to the resin during the harvesting or post-harvesting process. The impurities can be removed from the kemenyan resin by dissolving the resin in ethanol since some impurities like polysaccharides and lignin do not dissolve in ethanol [17]. From Table 1, it can also be observed that the cinnamic acid content sightly varies from $21.78 \%$ for grade VI resin to $24.89 \%$ for grade IV. These values lie in range of 23.87 to $27.29 \%$ reported by Aswandi and Kholibrina [7] for grade IV to grade VI resin, where the cinnamic acid content increases with the increases of resin quality. A TLC analysis was conducted to see whether cinnamic acid in the kemenyan resin was fully isolated or still mixed with other balsamic acid compounds. Cinnamic acid is considered pure if there is only one spot formed on the TLC plate after the elution process. The results of the elution process of cinnamic acid from kemenyan resin in this study is given in Table 2. The results showed that the cinnamic acid was successfully isolated since it has a similar polarity to ethyl acetate. The results resemble the previous finding by Waluyo, et al. [12] where the retention factor for cinnamic acid during a TLC plate analysis lies in the range of 0.125 to 0.875 and the retention factors increased with a higher concentration of ethyl acetate as the eluent. The purity of cinnamic acid isolated from the kemenyan resin also has been determined in this study as shown in Table 1, and lies in the range of 90.9 to $94.3 \%$. According to Waluyo, et al. [12], purity of the cinnamic acid is not influenced by the quality of the resin, but rather it is influenced by the isolation method used to extract cinnamic acid from the kemenyan resin.

\subsection{Pre-treatment of Kemenyan Barks to Increase the Extraction Yield of Saponin}

Pre-treatment effects of incubating kemenyan barks with Phanerochaete chrysosporium on the lignocellulose composition are presented in Table 3. The kemenyan bark contains $15.33-33.33 \%$ hemicellulose, $17.67-24 \%$ cellulose, $36.65-43 \%$ lignin, and $0.08-1.33 \%$ ash. The lignin content decreased with increasing incubation periods, reaching a maximum reduction of approximately $15 \%$ after being incubated with $P$. chrysosporium for $21 \mathrm{~d}$. According to Purwanti [18], P. chrysosporium was able to decrease $50 \%$ of lignin content in rice husk and up to $81 \%$ in corncob [19]. A lower value obtained in this study as compared to the reference is likely due to the difference in their chemical composition. The agricultural waste typically contains $15-20 \%$ lignin [20] whereas kemenyan barks used in this study had an initial lignin content of $43 \%$. Hence, a longer incubation period may be required to degrade most of the lignin as delignification processes typically have a low efficiency and require a longer duration [10]. After the incubation process, saponin was extracted from the pre-treated kemenyan barks and the total saponin content in the barks is illustrated in Figure 1. Total saponin content extracted from the pre-treated kemenyan barks increased with the incubation period. The highest total saponin content (7.02\%) was found after the incubation period of $21 \mathrm{~d}$, which was 7.5 -fold higher compared to when the kemenyan barks were not pre-treated with $P$. chrysosporium. $(0.93 \%)$. The results suggest that the reduction in lignin content on the cell wall of kemenyan barks may facilitate the extraction of saponin from the inside of the cell. Existing studies that report the extraction of saponin from kemenyan barks are very scarce. Hence, the results obtained in this study will provide an insight for further valorization of saponin from the kemenyan barks.

\subsection{Characteristics of Kemenyan Fruits}

The composition of fruit parts, as well as moisture content for unripe and ripe kemenyan fruits investigated in this study, are shown in Table 4 and Figure 2. On the one hand, ripe kemenyan fruits had a higher percentage of endocarp and endosperm ( $16.23 \%$ and $7.38 \%$, respectively) as compared to the unripe fruits $(12.31 \%$ and $6.84 \%$, respectively). On the other hand, unripe kemenyan fruits had a higher percentage of exocarp and mesocarp (80.85\%) as compared to the ripe fruits (76.39\%).

From Figure 2, it can be observed that unripe kemenyan fruits had a higher moisture content compared to the ripe fruits. The moisture content of exocarp and mesocarp, endocarp and endosperm for unripe fruits was $72.00 \pm 0.34 \%, 45.20 \pm 1.83 \%$ and $65.24 \pm 0.44 \%$, respectively. Meanwhile, the moisture content of exocarp and mesocarp, endocarp and endosperm for ripe fruits was $69.86 \pm 1.58 \%, 41.31 \pm 1.32 \%$ and $61.96 \pm 1.27 \%$, respectively. Primary growth tends to occur in young cells and since unripe fruits are dominated by young cells, they will have a higher moisture content as compared to the ripe fruits. The cells in ripe fruits, on the other hand, tend to differentiate, hence they will have a lower moisture content [21]. 
Table 2.

Retention factor for the elution of cinnamic of acid from kemenyan resin using different eluent ratio.

\begin{tabular}{c|c|c}
\hline Grade & Eluent ratio & Retention factor \\
\hline IV & \multirow{2}{*}{$1: 9$} & 0.25 \\
V & & 0.20 \\
VI & & 0.23 \\
\hline IV & $1: 1$ & 0.80 \\
V & & 0.78 \\
VI & \multirow{2}{*}{$7: 3$} & 0.80 \\
\hline IV & & 0.85 \\
V & & 0.83 \\
VI & \multirow{2}{*}{$8: 2$} & 0.85 \\
\hline IV & & 0.85 \\
V & \multirow{2}{*}{$1: 0$} & 0.83 \\
VI & & 0.83 \\
\hline IV & & 0.90 \\
V & & 0.86 \\
VI & & 0.88 \\
\hline
\end{tabular}

Table 3.

Lignocellulose content in kemenyan barks after pre-treatment with P. chrysosporium

\begin{tabular}{c|c|c|c|c|c}
\hline $\begin{array}{c}\text { Incubation } \\
\text { period (d) }\end{array}$ & $\begin{array}{c}\text { Hot water } \\
\text { soluble (\%) }\end{array}$ & $\begin{array}{c}\text { Hemicellulose } \\
\mathbf{( \% )}\end{array}$ & Cellulose (\%) & Lignin (\%) & Ash (\%) \\
\hline 0 & $16.33 \pm 1.25$ & $15.33 \pm 2.87$ & $24.00 \pm 2.16$ & $43.00 \pm 1.63$ & $1.33 \pm 0.47$ \\
\hline 7 & $16.67 \pm 2.36$ & $24.67 \pm 0.94$ & $17.67 \pm 1.25$ & $40.88 \pm 2.11$ & $0.12 \pm 0.06$ \\
\hline 14 & $10.00 \pm 1.41$ & $33.33 \pm 2.05$ & $18.33 \pm 1.89$ & $38.23 \pm 0.91$ & $0.10 \pm 0.04$ \\
\hline 21 & $19.33 \pm 5.31$ & $25.00 \pm 4.90$ & $17.67 \pm 1.7$ & $36.65 \pm 1.66$ & $0.08 \pm 0.03$ \\
\hline
\end{tabular}

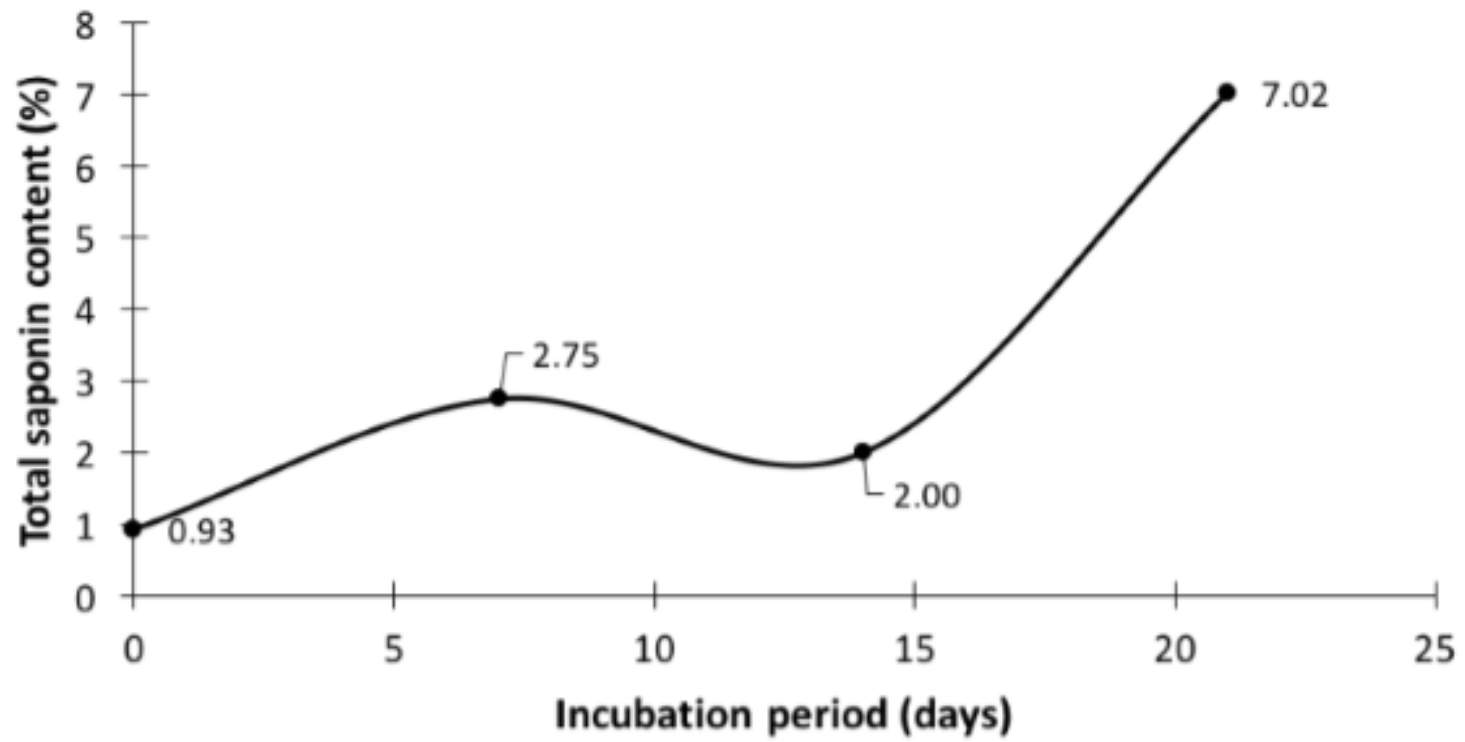

Figure 1.

Total saponin content from kemenyan barks after incubation with $P$. chrysosporium.

Table 4.

Composition of fruit parts for unripe and ripe kemenyan fruits.

\begin{tabular}{l|c|c}
\hline \multirow{2}{*}{ Kemenyan fruit parts } & \multicolumn{2}{|c}{ Composition (wet weight, \%) } \\
\cline { 2 - 3 } & Unripe fruits & Ripe fruits \\
\hline Exocarp and mesocarp & $80.85 \pm 1.58$ & $76.39 \pm 1.57$ \\
\hline Endocarp & $12.31 \pm 1.33$ & $16.23 \pm 1.72$ \\
\hline Endosperm & $6.84 \pm 0.27$ & $7.38 \pm 0.22$ \\
\hline
\end{tabular}




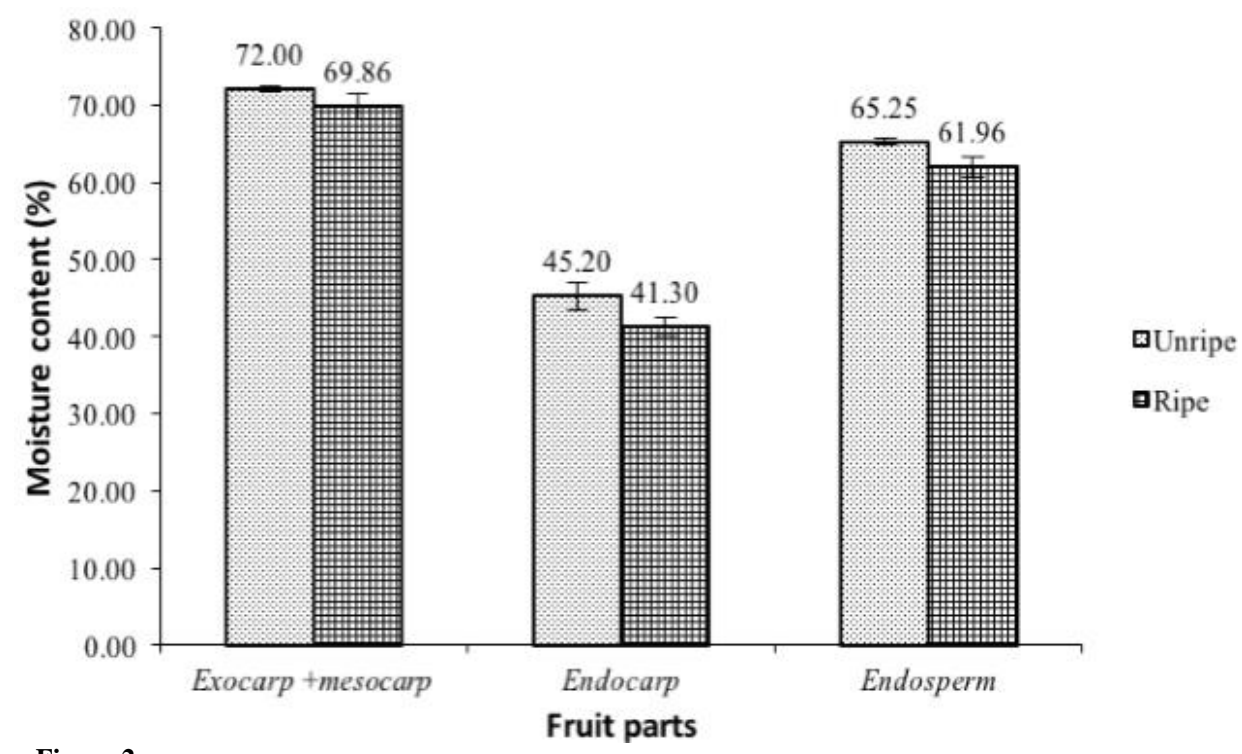

Figure 2.

Moisture content for unripe and ripe kemenyan fruit parts.

Table 5 shows the proximate composition of the unripe and ripe fruits. The ripe fruits had a relatively higher amount of crude protein and crude fat for both exocarp and mesocarp as well as endosperm in comparison to the unripe fruits. In contrast, the unripe fruits had a relatively higher amount of crude fiber for both exocarp and mesocarp and endosperm as compared to the ripe fruits. The endosperm for both unripe and ripe fruits contain a considerable amount of crude protein ( 8.97 to $10.23 \%$ ) and crude fat $(4.32$ to $7.36 \%)$ that can be valorized to produce valuable bioproducts such as protein hydrolysate and plant oil containing bioactive compounds.

Table 5.

Proximate content of unripe and ripe kemenyan fruit parts.

\begin{tabular}{l|c|c|c|c}
\hline \multirow{2}{*}{ Proximate content } & \multicolumn{2}{|c|}{ Exocarp and mesocarp } & \multicolumn{2}{c}{ Endosperm } \\
\cline { 2 - 5 } & Unripe fruits & Ripe fruits & Unripe fruits & Ripe fruits \\
\hline Ash (\%) & 1.28 & 2.66 & 2.66 & 2.22 \\
\hline Crude protein (\%) & 3.55 & 4.27 & 8.97 & 10.23 \\
\hline Crude fat (\%) & 0.50 & 0.91 & 4.32 & 7.36 \\
\hline Crude fiber (\%) & 27.49 & 22.95 & 7.58 & 6.01 \\
\hline
\end{tabular}

Table 6.

Fatty acids composition of crude fat isolated from the endosperm of unripe and ripe kemenyan fruits.

\begin{tabular}{l|c|c}
\multirow{2}{*}{ Fatty acid } & \multicolumn{2}{|c}{ Content (\%) } \\
\cline { 2 - 3 } Saturated fatty acid & Unripe fruits & Ripe fruits \\
\hline Lauric acid (12:0) & 7.83 & 4.21 \\
\hline Myristic acid (14:0) & 3.12 & 2.33 \\
\hline Palmitic acid (16:0) & 30.82 & 30.44 \\
\hline Stearic acid (18:0) & 9.10 & 8.11 \\
\hline Total saturated fatty acid & 50.87 & 45.09 \\
\hline Unsaturated fatty acid & \multicolumn{2}{|}{} \\
\hline Oleic acid(18:1) & 16.42 & 2.64 \\
\hline Linoleic acid (18:2) & 31.71 & 42.33 \\
\hline Cis-vaccenic acid (18:1) & 0.94 & 9.94 \\
\hline Total unsaturated fatty acid & 49.13 & 54.91 \\
\hline
\end{tabular}

The fatty acid composition of the crude fat isolated from the endosperm had been analyzed and the results are shown in Table 6. The most dominant saturated fatty acid was palmitic acid, for both the ripe and unripe fruits. Meanwhile, the dominant unsaturated fatty acid was linoleic acid. Overall, the saturated fatty acid content of crude fat isolated from the endosperm decreased as the ripeness of the fruits increased. In contrast, the unsaturated fatty acids content increased as the ripeness of the fruits increased. The results resemble the trend of previous studies by Msaada, et al. [22] and Prada, et al. [14] on Coriandrumsativum L. and Elaeisguineensis fruits, where saturated fatty acid content tends to decrease, and unsaturated fatty acid content tends to increase with the ripeness of the fruits.

Although the exocarp and mesocarp of kemenyean fruits contain relatively low amounts of crude fat $(0.50$ to $0.91 \%)$, they still contain an appreciable amount of crude protein $(3.55$ to $4.27 \%)$ that can be further valorized to increase the 
economic value of kemenyan plantations. For instance, the exocarp and mesocarp of kemenyan fruits may be utilized as a substrate for the cultivation of Hermetia illucens to produce protein-rich biomass [23].

\section{Conclusion}

The physical parameters and cinnamic acid content of different resin grades have been examined. Grade IV, V and VI resin contain 21.78 to $24.89 \%$ cinnamic acid and the isolated cinnamic acid had a purity of more than 90.9 to $94.3 \%$. The effect of delignification of kemenyan barks with Phanerocahete chrysosporium on the amount of extracted saponin from the barks and different fruit ripeness on the composition of the fruits also has been investigated. Pre-treated kemenyan barks are able to degrade $15 \%$ of the lignin after $21 \mathrm{~d}$ of incubation with Phanerochaete chrysosporium and increase the amount of extracted saponin up to 7.5-fold higher compared the non-pre-treated barks. The ripe kemenyan fruits had a higher protein and crude fat content as compared to the unripe fruits.

\section{References}

[1] P. M. Pauletti, H. L. Teles, D. H. S. Silva, A. R. Araújo, and V. S. Bolzani, "The styracaceae," Brazilian Journal of Pharmacognosy, vol. 16, pp. 576-590, 2006.Available at: https://doi.org/10.1590/s0102-695x200600040002.

[2] Ministry of Environment and Forestry, Retrieved from: http://ppid.menlhk.go.id/siaran pers/browse/2305, 2020.

[3] A. Hidayat, A. H. Iswanto, A. Susilowati, and H. H. Rachmat, "Radical scavenging activity of kemenyan resin produced by an Indonesian native pant, Styrax sumatrana," Journal of Korean Wood Science and Technologu, vol. 46, pp. 346-354, 2018.Available at: https://doi.org/10.5658/WOOD.2018.46.4.346.

[4] S. Hamm, J. Bleton, and A. Tchapla, "Headspace solid phase microextraction for screening for the presence of resins in Egyptian archaeological samples," Journal of Separation Science, vol. 27, pp. 235-243, 2004.Available at: https://doi.org/10.1002/jssc.200301611.

[5] M. Hovaneissian, P. Archier, C. Mathe, G. Culioli, and C. Vieillescazes, "Analytical investigation of styrax and benzoin balsams by HPLC-PAD-fluorimetry and GC-MS," Phytochemical Analysis, vol. 19, pp. 301-310, 2008.Available at: https://doi.org/10.1002/pca.1048.

[6] A. H. Iswanto, Y. S. Siregar, A. Susilowati, A. Darwis, R. Hartono, B. Wirjosentono, H. H. Rachmat, A. Hidayat, and W. Fatriasari, "Variation in chemical constituent of Styrax sumatrana wood growing at different cultivation site in North Sumatra, Indonesia," Biodiversitas, vol. 20, pp. 448-452, 2019.Available at: https://doi.org/10.13057/biodiv/d200221.

[7] A. Aswandi and C. Kholibrina, "The grading classification for Styrax sumatrana resins based on physico chemical characteristics using two-step cluster analysis," in IOP Conference Series: Materials Science and Engineering, 2020, p. 012013.

[8] Jayusman, Getting to know Kemenyan Tree (Styraxspp.) species with an unoptimized broad spectrum of usage. Jakarta: IPB Press, 2014.

[9] Chemical Book, "Saponin." Retrieved from https://www.chemicalbook.com/Price/Saponin.htm, 2021.

[10] B. C. Saha, N. Qureshi, G. J. Kennedy, and M. A. Cotta, "Biological pretreatment of corn stover with white-rot fungus for improved enzymatic hydrolysis," International Biodeterioration \& Biodegradation, vol. 109, pp. 29-35, 2016.Available at: https://doi.org/10.1016/j.ibiod.2015.12.020.

[11] M. Y. Abduh, L. W. Putri, and R. Manurung, "Effect of storage time on moisture content of Reutealis trisperma seed and its effect on acid value of the isolated oil and produced biodiesel," Energy Reports, vol. 5, pp. 1375-1380, 2019.Available at: https://doi.org/10.1016/j.egyr.2019.09.066.

[12] T. K. Waluyo, P. Hastoeti, and T. Prihatiningsih, "Characteristics and physicochemical properties of various qualities of frankincense in North Sumatra," Journal of Forest Products Research, vol. 24, pp. 47-61, 2006.

[13] Minarno, "Analysis of saponin content in leaves and petioles of Carica pubescens Lenne \& K. Koch," El-Hayah, vol. 5, pp. 143152, 2016.

[14] F. Prada, I. M. Ayala-Diaz, W. Delgado, R. Ruiz-Romero, and H. M. Romero, "Effect of fruit ripening on content and chemical composition of oil from three oil palm cultivars (Elaeis guineensis Jacq.) grown in Colombia," Journal of Agricultural and Food Chemistry, vol. 59, pp. 10136-10142, 2011.Available at: https://doi.org/10.1021/jf201999d.

[15] R. Datta, "Acidogenic fermentation of lignocellulose-acid yield and conversion of components," Biotechnology and Bioengineering, vol. 23, pp. 2167-2170, 1981.Available at: https://doi.org/10.1002/bit.260230921.

[16] GESTIS Substance Database, "Cinnamic acid," 2013.

[17] A. L. Horvath, "Solubility of structurally complicated materials: I. Wood," Journal of Physical and Chemical Reference Data, vol. 35, pp. 77-92, 2006.Available at: https://doi.org/10.1063/1.2035708.

[18] R. T. Purwanti, "The effectiveness of rice Husk biodelignification by white Rot Fungi phanerochaete chrysosporium with variation of incubation temperature and initial pH of substrate," Thesis Program Studi Biologi, Universitas Islam Negeri Sunan Kalijaga, Yogyakarta, 2016.

[19] Fadilah, D. Sperisa, K. Enny, and J. Arif, "Biodelignification of corn stalks with white rot fungus Phanerochaete chrysosporium," Equilibrium, vol. 7, pp. 7-11, 2008.

[20] T. Anindyawati, "Prospects of enzymes and lignocellulosic waste for bioethanol production," Cellulose News, vol. 44, pp. 49$56,2009$.

[21] L. Taiz and E. Zeiger, Plant physiology, 3rd ed. Sunderland: Sinauer, 2002.

[22] K. Msaada, K. Hosni, M. B. Taarit, T. Chahed, M. E. Kchouk, and B. Marzouk, "Changes on essential oil composition of coriander (Coriandrum sativum L.) fruits during three stages of maturity," Food Chemistry, vol. 102, pp. 1131-1134, 2007.Available at: https://doi.10.1016/j.foodchem.2006.06.046.

[23] M. Y. Abduh, M. H. Nadia, R. Manurung, and R. E. Putra, "Factors affecting the bioconversion of Philippine tung seed by black soldier fly larvae for the production of protein and oil-rich biomass," Journal of Asia-Pacific Entomology, vol. 21, pp. 836-842, 2018.Available at: https://doi.org/10.1016/j.aspen.2018.06.007. 